\title{
FASAKH NIKAH IS TALAK KHULU ' IN THE PERCEPTIVE OF MUQARANAH MAZAHIB FIL AL-FIQH AND MAQASHID SYARI'AH
}

\author{
Nurhadi
}

STAI Al-Azhar, Pekanbaru, Indonesia alhadijurnal@gmail.com

Received:24-07-2019; Revised:07-06-2020; Accepted: 11-06-2020;

ABSTRACT

Fasakh nikah or khulu' is the husband's divorce right which is given to his wife to break away from the marriage bond which is considered to have no benefit. This study is a study of muqaranah mazahib fil al-figh. Khulu 'according to the school of Daud al-Zhahiri, Ibnu Hazm represented, argues that the khulu' is the king's divorce (talak that can be reconciled). According to the Hanbali School represented by Ibn Qudamah that khulu' is the fasakh of marriage. Strengthened by Imam Ahmad with the argument of the authentic hadith of Ibn Abbas, as well as the opinion of the Shafi'iyyah school. The maqasid syari'ah review of khulu' in marriage with the maqasid Ammah and Khassah approach, then analyzed using circular theory by understanding the meaning of khulu' based on general benefit, then khulu 'is the wife's divorce, because talak can basically arise from the husband referred to as the rights of divorce and also from the wife referred to as divorce divorce or khulu' or fasakh. Then the wisdom of khulu' is the solution to the incomplete household that is not resolved, so that the wife is not neglected, the law allows the wife of the talak or divorces the husband with the concept of khulu' or fasakh in the religious court (sharia court), in return for divorce rights for the wife.

Keywords: Fasakh Nikah, Talak Khulu' and Maqashid Syari'ah

\section{INTISARI}

Fasakh nikah atau khulu' adalah hak perceraian suami yang diberikan kepada istrinya untuk melepaskan diri dari ikatan pernikahan yang dianggap tidak memiliki manfaat. Penelitian ini adalah penelitian muqaranah mazahib fil al-fiqh. Khulu' menurut mazhab Daud al-Zhahiri, Ibnu Hazm mewakili, berpendapat bahwa khulu' adalah perceraian (talak yang dapat direkonsiliasi). Menurut mazhab Hanbali diwakili oleh Ibn Qudamah bahwa khulu' adalah fasakh pernikahan. Diperkuat oleh Imam Ahmad dengan argumen hadis shahih Ibnu Abbas, serta pendapat mazhab Syafi'iyyah. Maqasid syari'ah mengulas khulu' dalam pernikahan dengan maqasid Ammah dan Khassah, kemudian dianalisis menggunakan teori sirkular dengan memahami makna khulu' berdasarkan manfaat umum, maka khulu' adalah perceraian istri, karena talak pada dasarnya dapat timbul dari suami sebagai hak perceraian dan juga dari istri disebut perceraian atau khulu' atau fasakh. Maka khulu' merupakan solusi untuk permasalahan rumah tangga yang tidak dapat diselesaikan, sehingga hak istri tidak diabaikan, hukum memperbolehkan istri menceraikan suami dengan konsep khulu' atau fasakh di pengadilan agama, sebagai imbalan atas hak perceraian untuk istri.

Kata Kunci: Fasakh Nikah, Talak Khulu’ dan Maqashid Syariah

\section{A. Introduction}

Divorce is part of marriage, because there is no divorce without marriage first, because it is 
the beginning of living together between a man and woman as husband and wife. While divorce is the end of the life of the husband and wife, everyone wants the marriage to be kept intact throughout the lifetime. ${ }^{1}$

In Islam, basically it is forbidden to divorce because this is contrary to the purpose of marriage, where marriage aims to obtain a family that is sakinah, mawadah and rahmah. This goal is mentioned in the compilation of Islamic Law article 3 "marriage aims to realize the domestic life of sakinah, mawaddah, and rahmah. ${ }^{2}$ The husband and wife must understand their rights and obligations as an effort to build a family, which means that the husband's obligation as the wife's right and the wife's obligation as the husband's right. Husband and wife must be responsible for meeting each other's needs to build a harmonious and peaceful family. One of the things that is important in the concept of a harmonious family is how the family responds to the problems it faces well. ${ }^{3}$ The implementation of the marriage contract is only a moment, but the journey that must be passed long and its consequences is very serious in managing the family, which is truly the realization of sakinah, mawaddah, wa rahamah, including the rights and obligations of each party and their life, not only in the world but also to the hereafter. Because of that God Almighty, mention the term marriage contract with the word miśaqan galizan (heavy promise). ${ }^{4}$

But in navigating the ocean of household life there must be things that are unexpected and beyond expectations, from building a harmonious love until a feud arises that destabilizes a married life that should be harmonious, it is all inseparable from the trials of Allah, both from husband or wife. If both parties can find a good solution there will certainly be a way out that can bring them to improve their relationship. But if you do not get a solution, Islam provides a solution to find a solution. After various efforts sought to maintain the integrity of the family, the final solution is to divorce. Even if hated by divorce, as in the Hadith of the Prophet mentioned: Meaning: Hadith from Abdullah Ibn Umar said: The Messenger of Allah, said: "The most halal thing hated by Allah is the divorce. ${ }^{5}$

Regarding this matter, Islam gives talak rights to the husband if his desire to separate through divorce, and the right of khulu' for the wife if the desire to part with the husband or divorce through giving a ransom for the husband. Divorce according to the term is the release of the rope of marriage and ending the relationship between husband and wife. ${ }^{6}$ Divorce is the last alternative to be taken if there is no other way, so for $k_{h u l u}$.

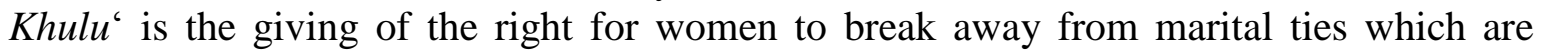
considered to have no benefit in return for the rights of divorce given to men. Intended to prevent the abuse of the husband with his talak rights, and to make the husband aware that the wife also has the same right to end the marriage. This means that in certain situations, a wife who is very

${ }^{1}$ Budi Muyasir, Essence Khulu 'Based on the Maqasid of Shari'ah (Comparative Study of the Opinion of Ibn Hazm and Ibn Qudamah), Syari'ah Faculty and Law of the State Islamic University Ar-Raniry DarussalamBanda Aceh, 2018.

${ }^{2}$ Directorate of Islamic Judicial Agency Development Department of Religion R.I, Compilation of Islamic Law in Indonesia (Jakarta: Ministry of Religion, 2011), 14.

${ }^{3}$ RI Ministry of Religion Research and Development Agency and Training Program for Al-Qur'an Mushaf, 2016, Interpretation of Al-Qur'an Thematic (Jakarta: Publishers I Can, 2012), 155.

${ }^{4}$ Abdul Hadi, Munakahat Fiqh and Legislation concerning Marriage (Semarang: Putaka Kausar, 2014), 7.

${ }^{5}$ Abu Dawud, Sunan Abu Dawud (Beirut: Dar Al-Fikr, t.th), 120.

${ }^{6}$ Sayyid Sabiq, Fiqh Sunnah, (cont. M. Tholib) (Bandung: Library Rizki Putra, 2016), 9. 
tormented due to her husband's behavior or a husband's condition has the right to demand divorce in return for something. ${ }^{7}$

In fact, khulu' istri can be asked by his wife to her husband due to the loss of feelings of love from his wife to her husband even though the husband did not commit an act that hurt his wife. The same right can also be done by the husband towards his wife, which is when the husband does not have any more feelings of love for his wife, by dropping divorce. The essence of the occurrence of a marriage engagement is the pleasure and love of both parties to live together. Therefore, if the love is no longer found in marriage, the pleasure will be destroyed, as a result the community will no longer be expected to benefit. If that happens, it is likely that they will be involved in the fellowship of Allah's provisions and they will be dragged into the areas which Allah forbids. ${ }^{8}$

With regard to the above, there are several ways in resolving household affairs as Fuad Said suggests that divorce can occur by: talak, khulu', fasakh, li'an and ila'. ${ }^{9}$ Because of the things mentioned earlier that divorce through some of these cases, the writer wants to focus on the study of khulu'. In Islam basically khulu' is not recommended, as divorce is not recommended in a marriage, because it is contrary to the purpose and principles of marriage in Islam.

In the opinion of the scholars regarding the khulu' case 'this is a wife who wants to separate herself from her husband by giving something in the form of compensation, namely giving compensation (ransom) to the husband. Whereas according to the compilation of Islamic law in 1991 in article 1 letter i, khulu' is divorce that occurs at the request of the wife by giving ransom or iwadh to and with the consent of the husband. ${ }^{10}$ As in the Compilation of Islamic Law and in fiqh, khulu' becomes one of the alternative paths that can be taken by the wife to make divorce claims against her husband. However, khulu' is not as a way to smooth out the wife in stripping off her marital ties, but khulu' leave a way out for the wife in the Sharia to separate from her husband, as the Sharia stipulates divorce for the husband towards his wife. The foundation of the khulu' determination 'is based on the word of Allah Almighty:" Divorce (which can be recited) twice. After that, you can refer again in a manner that is safe or divorce in a good way. It is not lawful for you to take back something from what you have given them, unless both are worried that they will not be able to carry out God's laws. If you are worried that both (husband and wife) cannot carry out God's laws, then there is no sin on both of them being paid by the wife to redeem themselves. These are the laws of God, so do not violate them. Those who violate the laws of their God are the wrongdoers. (Al-Baqarah: 229).

Fuqaha majority argues that khulu' is talak, this opinion was also expressed by Imam Malik. Abu Hanifah equates khulu' with divorce and fasakh simultaneously. The jurists who consider khulu' are talak, making them talak ba'in. That is because if the husband can refer his wife to 'iddah time, then the redeemer will no longer matter. ${ }^{11}$ Abu Tsaur argues that if khulu' does not use talak words, then the husband cannot refer to his wife, whereas if the word used is

\footnotetext{
${ }^{7}$ Budi Muyasir, Esence Khulu'....

${ }^{8}$ Rahmat Hakim, Islamic Marriage Law (Bandung: Loyal Library, 2015), 172.

${ }^{9}$ Fuad Said, Divorce According to Islamic Law (Jakarta: Reader al-Husna, 2014), 2.

${ }^{10}$ Directorate of Islamic Religious Court Coaching Department of Religion R.I, Compilation of Islamic Law in Indonesia, 14.

${ }^{11}$ Ibn Rusyd, Bidayatul Mujtahid, Analysis of the Fiqh of the Mujtahid, (c. Imam Gazali Said et al.) (Jakarta: Library of Amani, 2017), 558.
} 
talak, then the husband can refer it back. ${ }^{12}$

According to Ibn Hazm in his book al-Muhalla said that khulu' includes talak raj' $i$, except when her husband raises his wife with the last three lafaz talak or against women who have not yet been assassinated. So if the husband refers to his wife in 'iddah time the law may be either a woman likes or dislikes, and the husband returns what he receives from him. ${ }^{13}$ Whereas the opinion of the Hanbali School concerning khulu' there are two narrations, the first to say that khulu' is talak ba'in, while the second narrative says khulu' as separation (fasakh) and not talak. The legal basis of Imam Ahmad bin Hanbal said that khulu' is fasakh is based on a Hadith mentioned that a woman named Ar-Rubayyi' bint Mu'awwiz bin 'Afra did khulu' during the time of the Messenger of Allah, the Prophet told him to have one period. ${ }^{14}$ Likewise the opinion that was made blasphemous that the khulu' is the fasakh mentioned in the book al-Mugni Ibn Qudamah that based on the history of Abi Bakr, Ibn Abbas, Thawus, 'Ikrimah, Ishaq, Abu Tsaur and one of the opinions of Mazhab al-Shafi'i. ${ }^{15}$

Based on the explanation about khulu 'above, the author wants to further analyze the nature of khulu' as raj'i talak which, according to Ibn Hazm, is a Muslim scholar Zahiri and the opinion of Ibn Qudamah one of the great scholars of the Hanbali School that khulu' is fasakh, then with this the author raises this research using the theory of Maqasid syari'ah to the level of maqasid in the aspects of maqasid syari'ah al-khassah to find the nature of khulu' based on the two opinions of scholars who are the source of author research, while differences of opinion are a diversity in the School of Comparison. therefore to find balance and complement each other and fill between the two who are the primary sources of the author.

From the background above, the author would like to discuss how fasakh and khulu according to Ibn Hazm and Ibn Qudamah in the schools of Zhahiri and Hambali? Then how about the maqasid syariah khulu' in marriage?

\section{B. Result and Discussion}

\section{Daud al-Zhahiri's School of Opinion About The Khulu'}

The scholars have their own views in determining the results of their ijtihad both in the capacity level as mujtahid mutlaq, which is where the figure of Ibn Hazm is a scholar who has its own characteristics in his mindset, even though he is a follower of the Zahiri School, because he adheres to zhahir nas, but not it is undeniable if he is a mujtahid mutlaq who is free-minded and not bound by any school. ${ }^{16}$

Regarding Ibn Hazm's ability to find the law with his own ijtihad, this issue of ijtihad already has a degree as a mujtahid, which is the opinion of Ibn Hazm which tends to be more different and contradicts the ulema or the other Imam of the School. Ibn Hazm in terms of determining a law in a matter he had a handle in determining istinbat namely taking from the four sources of tasyri' according to Ibn Hazm namely Al-Qur'an, al-Sunnah, Ijma', and al-

\footnotetext{
${ }^{12}$ Budi Muyasir, Essence Khulu'...

${ }^{13}$ Ibn Hazm, Al-Muhalla, (Egypt: Idarah al-Tiba'ah Al-Munirah, 1352 H), 223.

${ }^{14}$ Abu Bakr ibn Abdillah bin Muhammad bin Abdillah, 'Aridhah al-Ahwadi bi Syarh Shahih at-Turmidzi (Beirut: Dar al-Kutub al-Ilmiyah, 1997), 127.

${ }^{15}$ Al-Muwafiq Ad-Din Abi Abdillah Bin Ahmad Bin Muhammad bin Qudamah, Al-Mugni (Riyadh: Dārul Al-limAlim, 1997), 274.

${ }^{16}$ Tengku M. Hasan As-Siddieqy, Principles of Handling Imam Mazhab, (Semarang: Library of Rizki Putra, 2015), 312.
} 


\section{Dalil. ${ }^{17}$}

Ibn Hazm in the matter of the khulu' he argues that khulu' is talak raj'i, as it has been quoted in his book Al-Muhalla: Khulu' is a ransom if a woman does not like her husband and she is afraid of not being able to give her husband's rights or afraid of being scolded by the husband. And a ransom is not lawful (legitimate) unless there is the pleasure of one of the two, then if the ransom or talak is dropped without the pleasure of both the ransom or divorce is null and void and the husband must return if the ransom has been taken from his wife and cancel a husband's divorce and it is also forbidden for the husband to torture his wife and for him the wife must give a ransom of all that he has and the divorce is talak raj'i, unless the husband is mentally ill three times and the woman has never been colonized, then the husband wants to refer to him in the 'iddah time it is permissible even though it is liked or not, and returned an item that has been taken from him to the wife, and is permitted to ransom by serving those who have been determined or restricted, and are not allowed to ransom with assets that are not good, but with good assets, he said, are understood by provisions it's clear. ${ }^{18}$

From the delivered statement, it was reaffirmed that Ibn Hazm said in his book, there were differences of opinion in this case, namely there was a group that said khulu' should not be done except with government permission, another group said it was not divorce, then experts differed that it is talak, then it is said that one more group believes that it is talak raj'i as we say. ${ }^{19}$

Based on the opinion that has been conveyed this can be concluded that he equates khulu' with talak, while the reason stated is that in Al-Qur'an a sura al-Baqarah verse 229 does not mention that khulu' is not divorce and there is no revelation that khulu' is divorce. Then according to Ibn Hazm that in the hadith concerning the wife of Thabit bin Qais, the Prophet ordered Thabit to take what he had given his wife, then divorce his wife. So from this hadith he argues that this shows the problem of the khulu' it is talak. ${ }^{20}$

As explained above Ibn Hazm argues that khulu' is talak raj'i on the grounds that Allah has explained the period of the iddah regarding the law of talak in a sura al-Baqarah verse 228 and a sura al-Talaq verse 2. Meaning: Women who are accused of holding back (waiting) three times quru'. They must not hide what Allah created in their womb if they believe in Allah and the Hereafter. And her husband has the right to refer to him in the waiting period, if they (the husbands) want ishlah. And women have rights that are balanced with their obligations according to the way they do. However, the husband has one level of strength over his wife. And Allah is Mighty, Wise (Al-Baqarah: 228). Meaning: If they are nearing the end of the 'iddah, then refer them well or release them well and witness with two witnesses who are just among you and you must establish that testimony because of Allah. Thus is given teaching with those who believe in Allah and the Hereafter. He who fears Allah, He will make for him a way out (AlTalaq: 2). ${ }^{21}$

Based on the Qur'anic proposition that Ibn Hazm has suggested that there should be no deviation from the provisions set by the passage, he further explained that it was not found in the Qur'an and the Hadith of the Prophet, nor was there an explanation of the existence of divorce

\footnotetext{
${ }^{17}$ Rahman Alwi, Method of Ijtihad Mazhab al-Zahiri, 54.

${ }^{18}$ Budi Muyasir, Essence Khulu'...

${ }^{19}$ Ibid.

${ }^{20}$ Rahman Alwi, Method of Ijtihad Mazhab al-Zahiri, 238.

${ }^{21}$ Budi Muyasir, Essence Khulu'...
} 
$b a^{\prime}$ in who cannot be referred back except three divorces at once or separately, for women who have not been indicted. This provision is based on the Qur'an about the law of divorce mentioned in a sura al-Baqarah verse 228 and a sura Al-Talaq verse $2 .^{22}$

Ibn Hazm regarding the above opinion uses the source of al-dalil's law, the fourth source in the qaidah ushul fiqh of the Zahiri School, in which he took zhahir nas on the Qur'an about talak found in a sura al-Baqarah verse 228 and al-Thalak verse 2 as the author mentioned, the two verses become references as a legal basis according to Ibn Hazm about the problem of referring and khulu '. Thus it can be said that istinbat used by Ibn Hazm with the method of al-postulate is the fourth source that directly takes from the nas, if traced further in using the theory of alproposil there are several divisions, one of which is istishab, after further research the theory used in this matter Ibn Hazm can be said by the istishab method, istishab referred to here is one of several types of division or expansion of al-dalil. It is this istishab theory which is often used in legal terms by Ibn Hazm and the Zahiri school of scholars. Because what is meant by istishab according to Ibn Hazm is the continuation of the original law stipulated by nas so that there is a proposition that changes it. ${ }^{23}$

As the word of God in the Qur'an: Divorce (which can be recited) twice. After that, you can refer again in a manner that is safe or divorce in a good way. It is not lawful for you to take back something from what you have given them, except if both are worried that they will not be able to carry out God's laws. If you are worried that both (husband and wife) cannot carry out God's laws, then there is no sin on both of them being paid by the wife to redeem themselves. These are the laws of God, so do not violate them. Those who violate the laws of their God are the wrongdoers (Al-Baqarah: 229)". ${ }^{24}$

And also the Hadith narrated Ibn Majah: Meaning: Abu Kuraib told us, Abu Khalid told us, from Hajjaj, from Amru bin Su'aib from Habibah from his grandfather, he said: That Habibah bint Sahlun was the wife of Thabit bin Qais bin Shamas. Thabit had a bad mood and his wife met the Messenger of Allah and said: "O Messenger of Allah! For Allah's sake, If it is not fear because of God, when he comes to me, I will surely spit in his face. The Messenger of Allah said: Do you want to return the garden? He said: Yes, the Messenger of Allah then said: Return to him the garden so the Prophet divorced both (H.R. Ibn Majah).

From the explanation above, it can be seen clearly that Ibn Hazm said that khulu' is talak raj'i because what happens in the khulu' problem is talak' and there is a period of 'iddah which can be used to refer to 'as narrated and we say: "Indeed khulu' is raj'i divorce and this is narrated from Said bin Musayyab woman who is khulu' if the husband wants to refer to him then we will return what has been received from his wife, in the 'iddah period and witness it refer". ${ }^{25}$

\section{Opinions of the Hambali School of Khulu,}

In a household, there are problems that arise so that it must arrive at the point of divorce when the problem cannot be resolved again by mediation or deliberation in a family custom, which is known as a way for wives to divorce because there are things that are already unable to bear again so that it becomes a misery in the wife's mind, both in serving the husband, and the attitude of the husband who does not obey the commands of the Rabb, and khulu' itself can occur

\footnotetext{
${ }^{22} \mathrm{Ibid}$.

${ }^{23}$ Ibn Hazm, Al-Ihkam Fi Usul Al-Ahkam, (Egypt: Al-Kutub Al-Misriyyah, t.th), 59.

${ }^{24}$ Budi Muyasir, Essence Khulu'...

${ }^{25}$ Ibid.
} 
when there is agreement from the husband, not simply in the khulu' case because the terms and conditions must be fulfilled to be valid for the implementation. ${ }^{26}$ As the word of Allah swt: Meaning: "...If you are worried that both (husband and wife) cannot carry out the laws of God, then there is no sin on both of them being paid by the wife to redeem themselves..." (Al-Baqarah: 229).

Here there is a right for a wife to redeem herself from a status that has a concern that is not harmonious in the household, for a wife who is unable to carry out the law of God, for her there is the right to pay for her husband. According to Imam Ahmad as mentioned in the Al-Mugni book written by Ibn Qudamah, he argues that khulu' does not need a judge. Khulu' is allowed without the knowledge of the sultan (Government). And this he relies on the traditions of Umar and Usman, because actually khulu' is fasakh (substitution contract). ${ }^{27}$

The problem of khulu' within the ulama of Hanabilah argues that khulu' occurs if there is iwad (ransom), as the definition of khulu' which has been stated by the number of scholars there is an indication of iwad if the occurrence of khulu'. According to Imam Ahmad bin Hanbal in the khulu' case the pillars must be fulfilled, namely lafaz or shigat even though the pronunciation does not indicate khulu', because the pronunciation spoken by the husband to his wife about the marriage breakup at the wife's request means that it contains the meaning khulu' and that can happen even though not pronounced with $k h u l u^{\prime}{ }^{28}$ This khulu' case, according to the view of the Hanbali sect of scholars, is one of the authors' references to compare the scholar Zahiri Ibn Hazm, to the opinion of Ibn Qudamah as the object of study on the meaning of khulu' based on these two ulama, especially Ibn Qudamah, a muslim scholar Hanbali is a mujtahid who has a special and very influential position. ${ }^{29}$

Regarding the narration of the hadith mentioned in the book of Ibn Qudamah in which Imam Ahmad stated, khulu' is the fasakh in one of the narrations it is said that khulu' is also talak $b a^{\prime} i n$ by the Syafii sect, but Imam Ahmad's history of the khulu' issue, from one of the two narrations says that the khulu' is faskh, and this is chosen by Abu Bakr, and is said by Ibn Abbas and Thawus and Ikrimah and Ishak and Abi Tsaur and one of the opinions of the Syafi'i in the second narrative is khulu' is talak ba'in, it was narrated by Sa'id bin Musayyab, Hasan, 'Atha', Qubaidhah, Shuraih, Mujahid, Abi Salamah bin Abdurrahman, Nakh'i, Syu'bi, Zuhri, Makhul, Ibn Abi Najih, Malik, Auza 'i, Tsauri and the Ashabu Ra'yi. ${ }^{30}$

As Usman, Ali, and Ibn Masud narrated, however, Ahmad weakened their narration. And prefer the opinion mentioned in the Hadith narrated by Ibn Abbas that we can see. Meaning: From Ibn Abbas, the wife of Thabit bin Qais met the Prophet and then said: Yes (O) Rasulullah! As a matter of fact I did not denounce Thabit bin Qais regarding morality and variety, but I feared infidelity in Islam. The Messenger of Allah replied: Do you want to restore the palm garden (which was made the first dowry) to him? "He replied: Yes, the Messenger of Allah then

\footnotetext{
${ }^{26}$ Ibid.

${ }^{27}$ Al-Imam Muwafiq al-Din Abdullah bin Ahmad bin Qudamah al-Maqdisi, Al-Ummah Fi al-Fiqh alHanbali, Al-Mugni Al-Syarhu Al-Kabir, (Beirut: Addaar Al-Kutub Al-Ulumiyah, 1996 ), 173-178.

${ }^{28}$ Al-Imam Muwaffiq al-Din Abdullah bin Ahmad bin Qudamah al-Maqdisi, Al-Mugni Al-Syarhu Al-Kabir, (Beirut: Dār al-Kutub al-Ilmiyyah, t.th), 182.

${ }^{29}$ Budi Muyasir, Essence Khulu'...

${ }^{30}$ Al-Imam Muwaffiq al-Din Abdullah bin Ahmad bin Qudamah al-Maqdisi, Al-Mugni, 182.
} 
called Thabit ibn Qais and recited back to him your garden and your wife's divorce once!" (H. An-Nasa'i). ${ }^{31}$

With regard to the issue of khulu' which is said to be the fasakh contained in the chapter on the validity of the hadith narrated by Ibn Abbas which states that khulu' is fasakh. ${ }^{32}$ And he also refers to the word of Allah SWT in a sura al-Baqarah verse 229: "Meaning: "Divorce (which can be recited) twice". Then Allah says which means: "then there is no sin on both of them paid by the wife to redeem themselves". Then God said: Meaning: Then if the husband is mental (after the second divorce), then the woman is no longer lawful for her until she marries another husband. "(Al-Baqarah: 230). ${ }^{33}$

Even though the explanation regarding khulu' must be based on the pronounced lafazh but this identifies khulu' it is clear in its provisions because of the existence of lafazh even without intention in his words. Then it is mentioned two talak and khulu', and talak afterwards even though with lafazh khulu' it is like divorce, but he has been considered four times (exceeding three). ${ }^{34}$

In the book Syarah Al-Mugni Al-Syarhul Kabir, it is explained about (lafaz) divided into two, namely: sarih and kinayah, and on lafaz sarih it is divided into three, namely: khala'tuki (I am a khulu') because knowledge and benefits have been determined for him brought in. ${ }^{35}$ So it is not permissible for him to remarry before (the wife) remarries another, and because of that we say khulu' it is fasakh, not forbidden for him (khulu') even though he does 100 times, and this is a difference whether he is separated without lafaz talak and not also intended. ${ }^{36}$ From the opinions expressed, we can understand that Ibn Qudamah in his book still insists that khulu' is a fasakh and this refers to the hadith narrated from Ibn Abbas.

\section{Khulu' and Fasakh Nikah in the Maqasid Syariah Review}

The study on the khulu' discussion which was based on the existence of differences of opinion became a comparative study of the School in the realm of Jurisprudence. By using a circular approach, the authors hope to find dimensions of change that complement each other.

In this discussion, which is the focal point, the writer seeks the essence by using a circular (dialogical) approach between various diverse arguments. So first we see the realm of the approach based on the definition and objectives to be achieved. According to Amin Abdullah, a circular (dialogical) approach is an approach that pays attention to the shortcomings and weaknesses of each opinion, and simultaneously improves. ${ }^{37}$

As in the matter of the khulu' the jumhur there are those who argue that khulu' is talak $b a^{\prime} i n$, and the prominent ulama of the Zahiri sect, Ibn Hazm argues that the khulu' is raj'i talak as well as the Hanbali School has the view that khulu' it is fasakh (cancellation of the contract) as the cancellation of a contract in muamalah..$^{38}$

Ibn Hazm said that khulu' included talak raj ' $i$, namely divorce which had a period for the

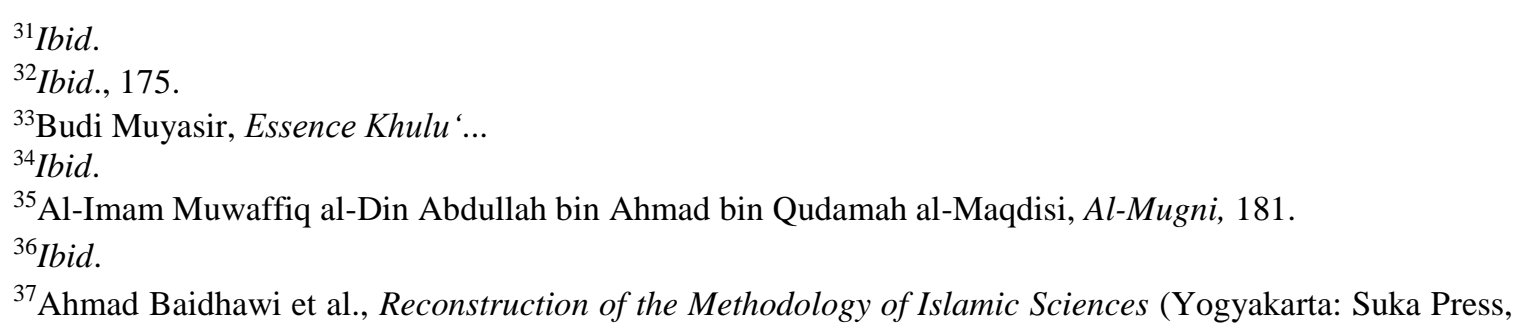
2013), p. 22.

${ }^{38}$ Budi Muyasir, Essence Khulu'... 
return of the husband's wife's stature or the return of mutual pleasure to continue the household separated by divorce. As for the period iddah which becomes the time of the second break, to have the opportunity to be lawful again, except when the husband drops the last divorce or has never been immersed. If her husband refers to it in the future ah whether the law is permissible without waiting for 'iddah it is finished whether the wife likes or dislikes and the husband returns to his wife what he has taken from him and then he continues the bond. That indeed, Allah has explained that husbands are more entitled to return to their wives in the waiting times. ${ }^{39}$ In this case it is also equipped with a verse about the period of reconciliation as Allah says in the Qur'an a sura al-Baqarah verse 228. Ibn Hazm who has a point of view regarding the khulu opinion 'is his raj'i talak back to the Qur'an' an.

Whereas the opinion quoted in the book of Ibn Qudamah in which Imam Ahmad said that the khulu' is the fasakh contained in the chapter on the validity of the hadith narrated by Ibn Abbas who stated that khulu ${ }^{6}$ is fasakh. ${ }^{40}$ In Islamic divorce discussions have been given the right to both through an orderly resolution of household problems, for the husband there is a divorce right and for the wife's side there is the right of khulu' based on the Qur'anic mentioned above, but that does not apply by itself, because a strong reason is needed to arrive at a rational context until the request to be divorced by the husband can be properly carried out with pleasure. ${ }^{41}$

This matter seen in the context of reality is a specificity in discussing maqasid, from the view of Ibn ur Assyria this can be attributed to this in the order of maqasid al-syari 'at alkhassah. In this dimension, on the one hand the maqasid subject is aimed at the mutation itself (al-'amal wa al-tasarrufat), and on the other hand it is focused on motivation, therefore Ibn 'Assyr ontologically resolves the maqasid al-syar'iyyat al-khassah to maqasid li syari' and maqasid li al-nas. For Ibn Assyria he dedicated maqasid al-syar 'iyyat al-khassah as a means (wasa'il) to realize maqasid al-syari'at al-'ammah. ${ }^{42}$ This Maqasid al-khassah identifies differences in divorce both arising from the husband's initiative and there are also from the wife's initiative, if it is from the husband then the absence of $w$ iwad in the implementation. But if the divorce is at the request of the wife, it is imposed on him ' $i w a d$. Therefore the Ontology of Talak is the initiative of husband and wife. But epistemologically the way it happens is different, because divorce is done from the husband can fall one divorce one or three, and if the divorce requested by the wife leads to the khulu' or fasakh, therefore, there is a difference in implementation between the two, so khulu ontology becomes dualism between raj'i or fasakh talak. As Allah says in the Qur'an a Sura al-Baqarah verse 229 means: If you are concerned that both (husband and wife) cannot carry out the laws of God, then there is no sin on both of them being paid by the wife to redeem himself. (Al-Baqarah: 229). ${ }^{43}$

From the above verse, it can be understood that divorce arises from the wife's initiative with the existence of the fidyah or soul given by the wife but there is no sin for both. Likewise this information is conveyed in the interpretation of the Qurthubi the scholars of the scholars

\footnotetext{
${ }^{39}$ Ibn Hazm, Al-Muhalla, 240.

${ }^{40}$ Al-Imam Muwaffiq al-Din Abdullah bin Ahmad bin Qudamah al-Maqdisi, Al-Mugni, 175.

${ }^{41}$ Budi Muyasir, Essence Khulu'...

${ }^{42} \mathrm{Jabbar}$, Validity of Maqasid al-Khalq (Study of the Thoughts of al-Ghazzali, al-Syatibi, and Ibn 'Assyria),

${ }^{43}$ Budi Muyasir, Essence Khulu'..
} 79. 
argue that taking payment for the divorce which is asked by the wife may. ${ }^{44}$ As Sayyid Sabiq also gives an understanding of khulu' which is called fidyah or ransom. Because the wife asks for divorce from her husband by paying a ransom from his wife to her husband by paying a ransom from the wife to the husband so that the husband wants to divorce her..$^{45}$

Etimologically fasakh itself comes from the word fasakha which means cancel. ${ }^{46}$ Or also means to revoke, abolish. ${ }^{47}$ Sayyid Sabiq is defined as canceling the marriage contract and giving up the relationship between husband and wife. ${ }^{48}$ And basically this fasakh law, mubah or may, there is no order or prohibition. ${ }^{49}$ Whereas if traced about the causes that led to the occurrence of Fasakh there are several things:

1) If the contract is perfect, then it is known that the wife who is married turns out to be a brother, then the contract must be effective. ${ }^{50}$

2) Syiqaq which is a fight between husband and wife that is impossible to reconcile. ${ }^{51}$

In the verse interpretation of the khulu', each cleric has an argument or has a dualism of viewpoints in understanding the scriptures about talak, which each opinion both has an interrelated element in one case with another, therefore circularity becomes a way to treating these opinions to complement each other on the khulu issue which says raj'i and khulu' talak who say fasakh, on the issue of the verse about divorce the author tries to gather several things that have relevance and need to be considered related to the nature of khulu', among others: ${ }^{52}$

1) The existence of juridical formalities, namely the Judge (Sultan), in which a Judge / Leader determines the decision whether he is a divorce (which can be referred to) or fasakh.

2) The existence of family relationships as a companion or as a mediator (Hakam) in finding a joint solution if the divorce issue can still be resolved.

3) Difficulties arise for both if it is decided directly on one of the opinions, if there is a desire to reconcile the principle of willingness without coercion for both.

4) On the issue of provisions in carrying out the law of Allah SWT. When there is a sense of fear of both, it is permissible to find solutions in the household.

5) Decisions that are determined by the judge or without a judge if he fasakh then the possibility of fasakh can be said to fall ba'in and cannot be reconciled. And if he is khulu' masa there is a period with the intention of talak which can be referred to then there is a period of iddah which must be fulfilled.

6) Linkages to 'iddah, if the judge decides khulu' as talak raj'i then there is a period waiting according to the provisions of the Sharia. And if both talak ba'in and triple divorce then it cannot return unless the wife has been married to another man.

As the explanation about khulu' above the differences found, but the goal remains one,

${ }^{44}$ Abi Abdillah Muhammah bin Ahmad bin Abi Bakr Al-Qurtubi, Jami'ul Ahkam Al-Qur'an, (Beirut: Muassasah Al-Risālah, 2016), 73.

${ }^{45}$ Sayyid Sabiq, Fiqh Sunnah (Jakarta: Gemilang Abadi Ink, 2013), 61.

${ }^{46}$ Amir Syarifuddin, Islamic Marriage Law in Indonesia, (Jakarta: Kencana, 2006), 190.

${ }^{47}$ Kamal Muchtar, Principles of Islamic Law About Marriage (Jakarta: Bulan Bintang, 1993), 212.

${ }^{48}$ Sayyid Sabiq, Fiqh Sunnah, 672.

${ }^{49}$ Amir Syarifuddin, Islamic Marriage Law in Indonesia, 244.

${ }^{50}$ Sayyid Sabiq, Fiqh Sunnah, 627.

${ }^{51}$ Amir Syarifuddin, Islamic Marriage Law in Indonesia, 245.

${ }^{52}$ Budi Muyasir, Essence Khulu '... 
namely with the intention of separating from a legitimate marriage bond, because there are various roots in terms of the above problems that lead to differences of opinion among the scholars, the authors see a correlation using the circular approach to obtaining the khulu' essence of paradigm differences but the opportunity to fill each other without the opinion being ruled out even though basically the Mazhab scholars have their opinions in this study. ${ }^{53}$

From the study that has been done, it can be understood based on the maqasid syari'ah on the nature of khulu' is the existence of a connection in the issue between the opinions of the scholars mentioned earlier. With the intention of the Sharia oriented to maqasid al-khassah can produce that divorce can be present from the husband's initiative and also talak from the initiative of the wife. ${ }^{54}$

Therefore, the lesson that can be learned from this study is to be able to deal with diverse possibilities in cases that occur. The authors take several things, among others: the time to think for husband and wife if the divorce process has been decided by the judge, and there is an opportunity for the judge's decision to reconcile or not, the decision that is appropriate not to be referred back because it has strong reasons accepted by the judge for convenience between the two parties. ${ }^{55}$

\section{Philosophy of Analysis}

After tracing the essence of khulu' from the perspective of the maqasid syari 'ah which aims to take the path of the masses in order to preserve and reject the things that cause damage from the materialization of the maslahah. So the use of the circular approach is a focal point for linking the two opinions of the ulama of the School above, which Ibn Hazm says in the book AlMuhalla that khulu' as talak raj' $i{ }^{56}$ In this case some of the ulama agreed, as narrated from Usman, Ali, Ibn Mas'ud and Jama'ah of the Tabi'in, that khulu' was talak. Therefore it was also stated by Imam Malik, al-Tsauriyyu, Auza'iyyu, Abu Hanifah and his Companions, and also from Syafii in one of his narrations. ${ }^{57}$ Anyone who wants khulu' is divorce which can be referred to or triple divorce, usually according to the imam of the intentions, and the companions of Ahlu $R a^{\prime} y i$ say that if the husband is divorced three then he falls three divorces, and if two are intended, he can refer back, because one sentence fell. In contrast to the opinion that the khulu' is fasakh, this opinion is expressed from the Hanabilah namely in Al-Mugni it is mentioned, based on the hadith in Ibn Abbas's statement which states that khulu' is fasakh. ${ }^{58}$

After reviewing these two views, it can be seen, if you want to justify one of the two opinions, it is fine, but in terms of circularity with values that complement each other for weaknesses and strengths in both, the writer judges based on orientation. Maqasid that the decision to determine the status of khulu' which leads to the right objective, then this authority is more effectively carried out by the judge so that dualism values are fulfilled towards both opinions. $^{59}$

The essence of khulu' remains in the talak orientation with the aim of presenting the

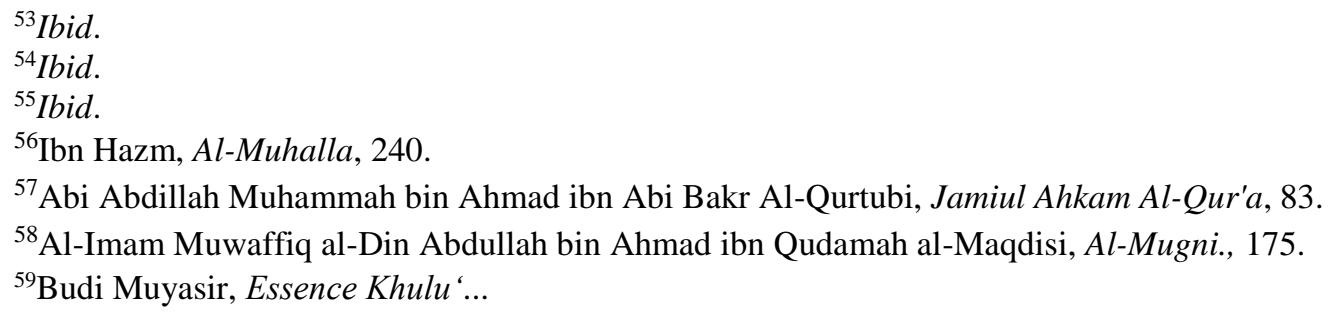


benefit if a case arises for a husband and wife, as the points of connection that need to be considered are related to the nature of khulu'. So again the writer concludes in this comparative study, the nature of khulu' namely maslahah which can be presented to both, whether it is a husband's divorce initiative which is not imposed on him 'iwad and the request of wife's divorce to give iwadi to what he has given, but in this is no sin for both. Because of that without disregarding the opinions of each of the scholars who became the primary material in this comparative study. ${ }^{60}$

The author also tries to gather several things related to the ontology of talak itself, among others:

1) The existence of juridical formalities namely Judge (Sultan), which is a Judge / Leader, who has the authority in the decision.

2) The family as a companion or as a mediator (Hakam) to find a joint solution.

3) If the unilateral decision is feared it will lead to contradictions in the opinions taken.

4) Fear in carrying out the law of Allah SWT. Being a reason that is still biased in the face of difficulties is with mutual openness.

5) Decisions that are determined by the judge or without a judge if he fasakh then the possibility of fasakh can be said to fall ba'in and cannot be reconciled. And if he is khulu' there is a period with the intention of talak which can be referred to then there is a period of iddah which must be fulfilled.

6) Providing a waiting period with the ruling of knitting divorce is better, because there is an opportunity to be able to reunite.

From the conclusions that the writer mentioned, it can be seen that basically the problem of seeking the essence of khulu' based on the maqasid syari'ah by using a circular approach is very relevant because there are advantages in the two opinions of those scholars who have syara' values filling each other's opinions. ${ }^{61}$

\section{Conclussion}

The discussion in the article that the author adopted is related to the maqasid syari'ah view of khulu' in family law. This author's study is a study of muqaranah mazahib fil al-fiqh, after the author has discussed it at length it can be concluded that:

1) According to the school of Daud al-Zhahiri, represented by Ibnu Hazm, argued that the khulu' is a king's divorce (talak that can be reconciled), this is a strong opinion in this school. According to the Hanbali School represented by Ibn Qudamah that khulu' is the fasakh of marriage. This was confirmed by the founder of his school, Imam Ahmad, in the authentic Hadith of Ibn Abbas, also followed by the Syafi'iyyah school of thought.

2) Review of maqasid syari 'ah about khulu' in marriage with the maqasid syari 'ah al-Ammah approach and maqasid syari'ah al-Khassah. If analyzed using a circular approach, namely understanding khulu' based on general benefit, then khulu' is a divorce from the wife's side, because talak can basically come from the husband and also from the wife. Then the wisdom of khulu' is the solution of the household complications that have not been resolved, so that the wife is not neglected, then the law allows the talak by wife or divorces her husband with the concept of khulu' or fasakh.

\footnotetext{
${ }^{60}$ Ibid.

${ }^{61}$ Ibid.
} 


\section{DAFTAR PUSTAKA}

Al-Abani, Muhammad Nasiruddin, Shahih Sunan An-Nasai, Fathurrahman, Jakarta: Reader Azzam, 2016.

Al-Maqdisi, Al-Imam Muwaffiq al-Din Abdullah bin Ahmad bin Qudamah, Al-Mugni, Beirut: Daar al-Kutub al-Ilmiyyah, t.th.

Al-Maqdisi, Al-Imam Muwafiq al-din Abdullah bin Ahmad bin Qudamah, Al-Umdah Fi alFiqh al-Hanbali, Al-Mugni al-Syarhu Kabir, Beirut: Addaar Al-Kutub Al-Ulumiyah, 1999.

Al-Qaradhawi, Yusuf, Grounding Shari'at Islam, Divine rules for Manusai, Bandung: Mizan Library, 2015.

Al-Qaradhawi, Yusuf, Sharia Fiqh; Islamic Modulation Between Textual Flow and Liberal Flow, happened: Arif, Bandung: Library Mizan, 2013.

Al-Qurtubi, Abi Abdillah Muhammah bin Ahmad bin Abi Bakr, Jamiul Ahkam Al-Qur'an, juz-4 Beirut Lebanon: Muassasah Al-Risalah, 2016.

Al-Syatibi, Al-Muwafaqat Fi Usul Al-Syari 'Ah, Cairo: Maktabah al-Tawfiqiyaah, 2003.

Alwi, Rahman, Ijtihad Mazhab al-Zahiri Method, Jakarta: Gaung Persada Press, 2015.

Asqalani, Imam Ibn Hajar, Shahih-Dha'if Bulughul Maram, (Muhammad Hanbal Safwan) Solo: Al-Qowam, 2013.

As-Siddieqy, Tengku M. Hassbi, Principles of Handling Imam Mazhab, Semarang: Library of Rizki Putra, 2007.

Auda, Jasser, Grounding Islamic Law Through Maqashid Syariah, Bandung: Mizan Pustaka, 2015.

Baidhawi, Ahmad, et al., Reconstruction of Islamic Science Methodology. Yogyakarta: Suka Press, 2013.

Bin Abdillah, Abu Bakar bin Abdillah bin Muhammad, 'Aridhah al-Ahwadi bi Syarh Shahih atTurmidzi, Beirut: Dar al-Kutub al-Ilmiyah, t.th.

Bin Yazid, Al-Hafizh abi Abdillah Muhammad, Sunan Ibn Majah, Egypt: Darul Hadits, 1998.

Dawud, Abu, Sunan Abu Dawud, Beirut: Dar Al-Fikr, t.th.

Fasa, Muhammad Iqbal, Reformation of the Understanding of the Maqasid Theory of Sharia Analysis of Systems Approach Jasser Auda, Journal of Islamic Studies, Vol. 13, No. December 2, 2016.

Hadi, Abdul, Munakahat Fiqh and Legislation concerning Marriage, Semarang: Putaka Kausar, 2014.

Hakim, Rahmat, Islamic Marriage Law, Bandung: Loyal Library, 2010.

Hasan, M. Ali, Comparison of School of Law, Jakarta: Raja Grafindo Persada, 2012.

Hazm, Ibn, Al-Fishlm Fi al Milal Wa al-Ahwa 'Wa al-Nihlm, Beirut: Dar Al Kutub Al Ilmiyah, 1999.

Hazm, Ibn, Al-Ihkam Fi Propose Al-Ahkam, Egypt: Al-Kutub Al-Misriyyah, t.th.

Hazm, Ibnu, Al-Muhalla, Idarah Tiba'ah Al-Munirah; Egypt, 1352 H Achmad Kuzari, Marriage as an Engagement, Jakarta: Raja Grafindo Persada, 2015.

Himayah, Mahmud 'Ali, Ibn Hazm wa Manhajuh fi Dirasah al-Adyan Terj. Himid Alkaf, Jakarta: Lentera Basritama, 2011.

Himayah, Muhammad Ali, Ibn Hazm, Biography, His Work and Studies on Religion, Jakarta: Lentra Basritama, 2011.

Husni Muadz, M., Anatomy of Social Systems: Normality Reconstruction of Intersubjectivity Relationships with System Approach, Mataram: IPGH, 2014. 
Ibn Mugirah, Al-Imam Abi Abdillah Muhammad Bin Isma‘il Ibn Ibrahim, Sahih Al-Bukhari, Beirut: Dar Al-Kutub Al-miImiyyah, 1992.

Islamic Religious Court Department of Religion R.I., Compilation of Islamic Law in Indonesia, Jakarta: Religious Affairs Department, 2011.

Jabbar, Validity of Maqasid al-Khalq (Study of the Thoughts of al-Ghazali, al-Syatibi, and Ibn 'Asur), Banda Aceh: Dissertation of the UIN Ar-Raniry Postgraduate Program, 2013.

Jaya, Asafri, Syari'ah According to Al-Syatibi. Jakarta: Raja Grafindo Persada, Directorate of Agency Development, 2006.

M. Zein, Satria Effendi, Ushul Fiqh, Jakarta: Kencana, 2015.

Mawardi, Ahmad Imam, Fiqh al-Aqlliyat Minority Fiqh and Evolution of al-Shari'ah from Concept to Approach, Yogyakarta: Lkis, 2010.

Ministry of National Education, Large Indonesian Language Dictionary, Jakarta: Balai Pustaka, 2014.

Moloeng, Lexy J., Qualitative Research Methodology, Bandung: Rosada Karya Youth, 2011.

Muchtar, Kamal, Islamic Law Principles About Marriage, Jakarta: Bulan Bintang, 2012.

Muyasir, Budi, Essence Khulu Based on the Maqasid of Shari'ah (Comparative Study of the Opinion of Ibn Hazm and Ibn Qudamah), Syari'ah Faculty and Law of the State Islamic University Ar-Raniry Darussalam-Banda Aceh, 2018.

Qudamah, Ibn, Al-Mugni, Ahmad Hotib, Faturrahman, Jakarta: Reader Azzam, 2007.

Rahmad, Jalaluddin, Communication Research Methods, Bandung: Youth Rosdakarya, 2015.

Republic of Indonesia Ministry of Religion Research and Development Agency and Training Center for Al-Qur'an Mushaf, Thematic Tafsir al-Quran, Jakarta, publisher, 2008.

Rusyd, Ibnu, Bidayatul Mujtahid, Fiqh Analysis of Mujtahid, Imam Gazali Said et al, Jakarta: Pstaka Amani, 2015.

Sabil, Jabbar, Circular Approach in School Comparative Studies, Syari'ah Media Forum for Islamic Law Studies Pranata Sosial vol 18. No, 1, 2016.

Sabiq, Sayyid, Fiqh Sunnah, Jakarta: Eternal Gemilang Ink, 2013.

Sabiq, Sayyid, Fiqh Sunnah, M. Tholib, bandung: Library of Rizki Putra, 2016.

Said, Fuad, Divorce According to Islamic Law, Jakarta: Reader Al-Husna, 2014.

Sukanto, Soerjono, Normative Legal Research A Brief Overview of, Jakarta: Rajawali, 2010.

Syarifuddin, Amir, Ushul Fiqh, Jakarta: Kencana, 2014.

Syarifuddin, Amir, Islamic Marriage Law in Indonesia, Between Munakahat Fiqh and Marriage Law, Jakarta: Kencana, 2016. 